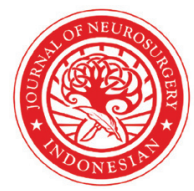

Indonesian Journal of Neurosurgery

\section{Aneurysmal bone cysts: Case report and literature review}

\author{
Loraine Quintana-Pajaro 1,2, Cristian Camilo Blanco-Teherann ${ }^{1,2}$, \\ Daniela López-Cepeda ${ }^{1,2}$, Luis Rafael Moscote-Salazar ${ }^{2,3^{*}}$, \\ Alfonso Pacheco-Hernandez ${ }^{2,3}$, Amit Agrawal ${ }^{3}$, Harsh Deora ${ }^{3}$, \\ Alexis Rafael Narvaez-Rojas ${ }^{3}$
}

'University of Cartagena. Cartagena de Indias, Colombia.

${ }^{2}$ Centro de Investigaciones Biomedicas (CIB), Universidad de Cartagena,

Cartagena, Colombia.

${ }^{3}$ Department of Neurosurgery. University of Cartagena. Cartagena de Indias, Colombia

\section{*Corresponding to: \\ Luis Rafael Moscote-Salazar; Facultad de Medicina, Campus de Zaragocilla, Universidad de Cartagena, Cartagena de Indias, Colombia; \\ mineurocirujano@aol.com}

Received: 2020-12-22

Accepted: 2021-03-13

Published: 2021-08-14

\section{ABSTRACT}

Background: Aneurysmal bone cysts $(\mathrm{ABC})$ are benign lesions with great vascularization and expandability. They represent approximately $1 \%$ of all bone tumors. These lesions are characterized by having multiple cavities filled with blood. In most cases, they are located in the thoracic and lumbar region. In this article, we aimed to present a clinical case and followed by review of relevant literature regarding pathophysiology, clinical, diagnostic and therapeutic aspects of this pathology.

Case presentation: A 41-year-old woman came with chief complaint of developing pain in the left hip, right gluteal region, and right posterior thigh for last 10 months. We performed hip plain x-ray, which suggested a left hip injury. Further investigation using computed tomography and magnetic resonance imaging were performed and revealed tumor of the left hip. A biopsy guided by TAC was performed. The histopathologic examination revealed numerous small vascular spaces lined with endothelial cells, abundant pools of red blood cells were seen, and hemosiderin pigment was seen at places along with giant cells, which was suggestive of $A B C$.

Conclusion: Aneurysmal bone cysts are lesions that represent a small percentage of the total osseous tumors. Sacral localization is rare and the manifestations are nonspecific.

Keywords: Aneurysmal bone cysts, bone tumor, iliac, sacral

Cite This Article: Qiuntana-Pajaro, L., Blanco-Teheran, C., Lopez-Cepeda, D., Moscote-Salazar, L.R., Pacheco-Hernandes, A., Agrawal, A., Deora, H., Narvaez-Rojas, A.R, . 2021. Aneurysmal bone cysts: Case report and literature review. Indonesian Journal of Neurosurgery 4(2): 78-82. DOI: 10.15562/ijn.v4i2.105

\section{INTRODUCTION}

Aneurysmal bone cysts (ABC) are benign lesions, non neoplastic, with great vascularization and expandability. They represent approximately $1 \%$ of all bone tumors and were first described by Van Arsdale. $^{1,2}$ Generally, patients with these lesions have neurological and somatic pain symptoms. There may be rigidity or even the presence of a palpable mass. ${ }^{3-7}$ Initially, $\mathrm{X}$-rays are used for initial diagnosis but they are unspecific and do not reveal ABC appearance. Therefore, other specialized studies are performed such as computed tomography, magnetic resonance, bone scan and biopsy. ${ }^{5}$

The treatment is still controversial, so we do not yet have a preference toward another. However, surgery is the most common treatment with the complete resection having the least recurrence rate. It can also be managed with adjuvant treatments such as radiotherapy, selective arterial embolization, among others. ${ }^{3,8-11}$
In this article, we aimed to present a clinical case and followed by review of relevant literature regarding pathophysiology, clinical, diagnostic and therapeutic aspects of this pathology.

\section{CASE PRESENTATION}

A 41-year-old woman came with chief complaint of developing pain in the left hip, right gluteal region, and right posterior thigh for last 10 months which affected her daily activities. She was managed with analgesics and antiinflammation medication without obvious improvement. The pain was worsening and followed by increased analgesic doses. On physical examination, we found normal vital signs and hydrated oral mucosa. Tenderness over right hip was negative.

We performed hip plain x-ray, which suggested a left hip injury (Figure 1). Further investigation using computed tomography and magnetic resonance imaging were performed and revealed tumor of the left hip (Figure 2). A biopsy guided by computed axial tomography was performed. The histopathologic examination revealed numerous small

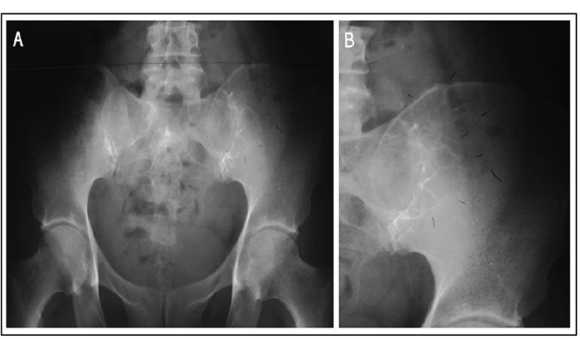

Figure 1. Preoperative $\mathrm{x}$-ray examination. A. Anteroposterior pelvis $\mathrm{x}$-ray. Well-defined lesions and edges were observed with a honeycomb pattern at the level of the left iliac bone near the sacroiliac joint. B. Anteroposterior $\mathrm{x}$-ray of the left hip. Aneurysmal bone cysts were seen in the left iliac bone. Notice the pattern of destruction. The bone was expanded but the lesions were marginalized by cortical bone. 


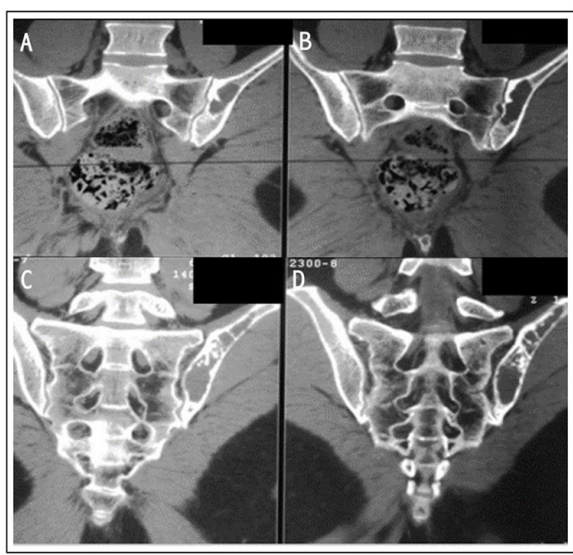

Figure 2. Coronal tomographic slices of the pelvis. A. and B. showed presence of double fluid level within the injury. C. and D. showed presence of septa inside the lesion with characteristics of soap bubbles.

vascular spaces lined with endothelial cells, abundant pools of red blood cells were seen, and hemosiderin pigment was seen at places along with giant cells, which was suggestive of $A B C$.

We proceed to perform excisioncurettage and bone-grafting surgery. Patient evolves satisfactorily and discharged after 10 days.

\section{DISCUSSION}

Aneurysmal bone cyst was firstly described by Van Arsdale in 1893 as ossifying hematomas, and in 1942 the term of ABC was started to being used. ${ }^{12}$ These lesions are benign, tumor-like, locally aggressive and highly vascular. They grow quickly and predominantly inside long bones with filled cystic cavities, ${ }^{4,-9,13}$ and multiple internal septations of varying thickness. ${ }^{3}$

$\mathrm{ABC}$ is usually found in young patients between the first and second decade of life and predominantly in women. They represent $1 \%$ of all primary bone tumors. ${ }^{8,13}$ The predilections are femur, tibia, humerus, spine, pelvis, ribs, small bones of the hands and feet. ${ }^{14}$ As many as 10 - $30 \%$ occurs in spine with predominance of the lumbar spine and equal occurrence in thoracic and cervical spine. ${ }^{3}$

At present, the pathophysiological process of aneurysmatic bone cysts formation is still not completely elucidated. ${ }^{3,4,13}$ Multiple theories have been proposed that can be grouped into local vascular alteration, ${ }^{14,15}$ failure in bone maturation ${ }^{16}$ and chromosomal modifications (translocation of $\mathrm{t}(16 ; 17)$ (q22;p13)). ${ }^{17}$ The local vascular alteration may be due to secondary to preexisting bone tumor such as giant cell tumor, osteoblastoma, osteosarcoma, and chondroblastoma; failure in vascular repair due to traumatic injury; and vascular malformation in bone. ${ }^{14,15}$

In the 1990s, Kransdorf and Sweet proposed that $\mathrm{ABCs}$ were the secondary changes to a vascular malformation which was caused by evolutionary alteration of a preexisting bone tumor. It led to the formation of a second lesion in the bone that masked the primary bone pathology that triggering it. ${ }^{5}$

Increase of local vascular pressures triggers an osteolytic-osteogenic process in the trabeculae of the affected bone which produces the appearance of multiloculated cavities filled with blood. ${ }^{15,17}$ This process consisted of 4 phases. In the first stage, the osteolysis predominates and in second phase, the lesion grows and expands which cause thinning of the bone. The third and fourth phase are characterized by soap-bubble pattern and healing process, respectively. The latter is distinguished by the ossification of the lesion and only a small group of these patients reaches this stage. ${ }^{14}$

Therefore, at the end of the 1990s, the study by Panoutsakopoulos et al. showed that some $\mathrm{ABCs}$ had a genetic component that could trigger the appearance of these tumors. These chromosomal mutations consisted of translocations of chromosomes 16 and $17 .^{18}$ These findings were similar to study by Oliveira et al. in 2004 who analyzed 8 cases and found that recurrent translocations in these chromosomes cause the juxtaposition of CDH11 and USP6 (ubiquitin-specific protease), increasing the transcription of this protease. ${ }^{19}$

ABCs usually occur between the first and second decade of life with a predominance of female and frequently occur in spine (lumbar, cervical and thoracic). At least $75 \%$ of them were located in thoracolumbar spine. ${ }^{4}$ Patients usually present with neurological symptoms and somatic pain associated with the compression of the involved nerve root, rigidity, presence of a palpable mass, and spinal deformity or acute vertebral collapse. ${ }^{3,4,6,7,20}$ About $10 \%$ of patients with this condition may have scoliosis or even kyphosis. ${ }^{5}$

Initially, spinal radiographs should be performed as initial work up examination, although nonspecific and do not reveal the findings of aneurysmal bone cysts. ${ }^{9}$ Further radiological examination should be accordance with radiologist and ability to establish the definitive diagnosis and differential diagnosis with specialized examinations (computed tomography, nuclear magnetic resonance, bone scan and biopsy) as well as clinical data. ${ }^{5}$

Computed tomography and magnetic resonance imaging are more reliable tests when suspecting $\mathrm{ABC}$ due to its ability to evaluate the complex bone anatomy of the spine. Computed tomography often revealed the pattern of soap bubble which is typical of a lytic lesion and the interruption of the cortex. ${ }^{4,5}$

Magnetic resonance imaging (MRI) allows to visualize a well-defined lesion with lobulated contours and presence of liquid inside of it. Internal septa that show a decrease in the signal presumably due to the presence of fibrous tissue. ${ }^{5}$ The fluid characteristics of $\mathrm{ABC}$ are better explored in MRI. ${ }^{5,10}$ Bone scintigraphy shows increased uptake of radionuclides in the peripheral area of the lesion in most cases. ${ }^{5}$ In some patients where the radiological findings are inconclusive, open biopsy is necessary to establish the definitive diagnosis because, it can determine grading and signs of malignancy of the tumor. ${ }^{6,32}$

ABC could be confused with a malignant tumor due to its fast-growing characteristic. Therefore, it is important to specify the exact location of the lesion, size, extension, accessibility of injury and risk of neurological involvement at the time of diagnosis. ${ }^{9}$ The differential diagnosis of this tumor are including giant cell tumor, calcification, solitary bone cysts, lowgrade osteosarcoma and telangiectatic osteosarcoma. ${ }^{7,13}$

The main treatment of $\mathrm{ABC}$ is controversial. However, surgery is one of the most common treatment which includes intralesional curettage and bone graft. ${ }^{3,89}$ In addition, radiotherapy is used 
Table 1. Summary of literature reporting case of aneurysmal bone cyst in the sacrum

\begin{tabular}{|c|c|c|c|c|c|c|}
\hline Authors & Year & Case & Age & Gender & Clinical manifestations & Duration of symptoms \\
\hline \multirow{6}{*}{ Zileli, et al. ${ }^{9}$} & 2013 & 6 & 29 & $\mathrm{M}$ & Low back pain & 24 months \\
\hline & & & 32 & $\mathrm{~F}$ & Left leg pain, left monoparesis & 12 months \\
\hline & & & 43 & M & Low back and leg pain & 1 month \\
\hline & & & 15 & M & Low back and left leg pain, paraparesis & 3 months \\
\hline & & & 13 & $\mathrm{~F}$ & Low back and left leg pain & 12 months \\
\hline & & & 22 & $\mathrm{~F}$ & Low back pain, paraparesis & 12 months \\
\hline Pogoda, et al. ${ }^{13}$ & 2003 & 1 & 17 & $\mathrm{~F}$ & $\begin{array}{l}\text { Moderate abdominal pain and intermittent weakness of } \\
\text { right leg }\end{array}$ & 4 weeks \\
\hline Codd, el al..$^{15}$ & 2006 & 1 & 8 & M & Low back pain & 4 months \\
\hline Mulhall, et al..$^{16}$ & 2003 & 1 & 15 & M & Low back pain & 2 months \\
\hline Aydın, el al..$^{20}$ & 2016 & 1 & 14 & $\mathrm{~F}$ & Sacral and leg pain & 24 months \\
\hline \multirow[t]{10}{*}{ Brastianos, et al. ${ }^{21}$} & 2009 & 10 & 64 & $\mathrm{~F}$ & $\begin{array}{l}\text { Low back pain, weakness of the right foot loss of } \\
\text { sensation and tingling }\end{array}$ & $8-10$ years \\
\hline & & & 26 & $\mathrm{~F}$ & Low back pain & 3 months \\
\hline & & & 39 & M & Constipation and bladder dysfunction & 1 year \\
\hline & & & 16 & $\mathrm{~F}$ & Low back pain & 3 months \\
\hline & & & 32 & M & Low back pain and radiation to right leg & - \\
\hline & & & 60 & $\mathrm{~F}$ & Low back pain with weight loss & 7 months \\
\hline & & & 57 & M & Low back pain and difficulty walking & 5 months \\
\hline & & & 10 & $\mathrm{~F}$ & Left leg pain & - \\
\hline & & & 5 & $\mathrm{~F}$ & Back pain and difficulty walking & 3 months \\
\hline & & & 17 & $\mathrm{~F}$ & Low back pain and bowel and bladder dysfunction & - \\
\hline Jevtich $^{22}$ & 1988 & 1 & 60 & M & Low back pain, radiating along the right leg & - \\
\hline Simm, et al. ${ }^{23}$ & 2013 & 1 & 8 & M & Left posterior thigh pain & 3 weeks \\
\hline Skubitz, et al. ${ }^{24}$ & 2015 & 1 & 27 & M & Low back pain & - \\
\hline Vester, et al. ${ }^{25}$ & 2010 & 1 & 19 & $\mathrm{~F}$ & Lower back pain also affecting thigh and knee & 6 months \\
\hline Ghermandi, et al. ${ }^{26}$ & 2016 & 1 & 42 & $\mathrm{M}$ & Lumbar back pain & - \\
\hline Nas, et al. ${ }^{27}$ & 2015 & 1 & 32 & M & $\begin{array}{l}\text { Pain radiating to thighs and anal region, numbness and } \\
\text { incontinence }\end{array}$ & - \\
\hline Doss, et al..$^{28}$ & 2014 & 1 & 16 & M & Sacral and leg pain & 4 months \\
\hline Yildırım, et al. ${ }^{29}$ & 2007 & 1 & 13 & M & Left hip and low back pain, related to accident & 4 months \\
\hline Rajadhyaksha, et al. ${ }^{30}$ & 2003 & 1 & 13 & $\mathrm{~F}$ & Pain in the right buttock and posterior thigh. & - \\
\hline Derinkuyu, et al..$^{31}$ & 2016 & 1 & 13 & $\mathrm{~F}$ & Difficulty in walking, left leg pain, and lower back pain & 1 month \\
\hline
\end{tabular}

Table 2. Summary of treatment options for aneurysmal bone cyst

Treatment options

Surgery

Radiotherapy

Selective arterial embolization

Bisphosphonate injection

Percutaneous cryoablation

Denosumab therapy

\section{Description}

It was considered the main treatment and the recurrence rate depends on resection, or curettage with bone graft or without it. Resection provided lower rate of recurrence.

In most cases, it was used as an adjuvant treatment. However, there was risk of developing a malignancy. The dose was really important for the outcome of this treatment.

It is performed as a preoperative treatment to reduce bleeding in the surgery. However, it could have some complication such as the risk of embolizing arterial supply to adjacent normal tissue and embolic complications.

First reported in 2013 by Simm, et al. when administered in children and adolescents with ABC. Its effectiveness to inhibit osteoclastic activity and reduction of inflammation was demonstrated. However, it was considered lack of evidence for its use due to adverse effects of osteonecrosis.

It should be considered when the goal of treatment was to reduce tumor size.

This was a human monoclonal antibody that bind to and inhibit receptor-activator of nuclear kappa beta ligand (RANKL). RANKL was expressed in specific cells of ABC. It was recommended to patients who do not respond to selective arterial embolization and contraindicated for surgery.
Reference

[3], [4], [8], [9], [10], [12], [16], [28], [33]

[3], [4], [7], [8], [9], [12], [13], [16], [34]

$[1],[3],[9], \quad[11]$, [12], [13], [15], [16], [35]

[3], [23]

[3]

[36], [37] 
as an adjuvant treatment. However, there is risk of inducing malignancy in the $\mathrm{ABC}$ due to radiotherapy. It is believed that radiotherapy should only be prescribed in patients where surgery is contraindicated. This type of treatment is completely contraindicated for those young patients with lesions near the spine due to the risk of developing myelopathies and the potential to induce spinal deformity. ${ }^{4}$

For the treatment of $\mathrm{ABC}$, we found some methods that are minimally invasive, such as selective arterial embolization, sclerotherapy, bisphosphonate injection, cementoplasty, percutaneous ablation, among others that have been used recently. ${ }^{3,9,10}$ The summary of treatment option for ABC can be seen in Table 2 .

In present time, $\mathrm{ABC}$ has an excellent prognosis. However, it is recommended to monitor these patients continuously there are still possibility of recurrency. In addition, it must be emphasized that early and adequate diagnosis of these patients leads to better treatment and therefore a lower recurrence rate and better prognosis. ${ }^{8,9,15}$

\section{CONCLUSION}

Aneurysmal bone cysts are lesions that represent a small percentage of the total osseous tumors. Sacral localization is rare and the manifestations are nonspecific. It is very important to rule out the presence of a primary bone lesion such as osteosarcomas and the possibility of recurrent bone cysts.

\section{CONFLICT OF INTEREST}

None of the authors of this paper has a financial or personal relationship with other people or organizations that could inappropriately influence or bias the content of the paper.

\section{FUNDING}

Authors declare no sponsorship regarding this manuscript.

\section{AUTHOR CONTRIBUTION}

Authors contribute equally in the making process of this manuscript.

\section{REFERENCES:}

1. Tarantino R, Piccirilli M, Anichini G, Delfini R. Benign osteoblastoma of the odontoid process of the axis with secondary aneurysmal bone cyst component: A case report. Neurosurg Rev. 2008; 31(1): 111 - 115. https://doi.org/10.1007/ $\underline{\text { s10143-007-0113-5. }}$

2. Namazi H, Mozaffarian K. Practice pearl: A novel use of tranexamic acid for decreasing the blood loss of aneurysmal bone cyst ablation. Ann Surg Oncol. 2007; 15(1): 383 - 384. https:// doi.org/10.1245/s10434-007-9614-2.

3. Tsoumakidou G, Too CW, Garnon J, Steib J-P, Gangi A. Treatment of a spinal aneurysmal bone cyst using combined image-guided cryoablation and cementoplasty. Skeletal Radiol. 2015; 44(2): 285 - 289. https://doi.org/10.1007/ s00256-014-1967-6.

4. Saccomanni B. Aneurysmal bone cyst of spine: A review of literature. Arch Orthop Trauma Surg. 2008; 128(10): 1145 - 1147. https://doi. org/10.1007/s00402-007-0477-6.

5. Kransdorf MJ, Sweet DE. Aneurysmal bone cyst: Concept, controversy, clinical presentation, and imaging. AJR Am J Roentgenol. 1995: 164(3): 573 - 580. https://doi.org/10.2214/ ajr.164.3.7863874.

6. Mankin HJ, Hornicek FJ, Ortiz-Cruz E, Villafuerte J, Gebhardt MC. Aneurysmal bone cyst: A review of 150 patients. JClin Oncol. 2005; 23(27): 6756 - 6762. https://doi.org/10.1200/ LCO.2005.15.255.

7. Thakur NA, Daniels AH, Schiller J, Valdes MA, Czerwein JK, Schiller A, et al. Benign tumors of the spine. J Am Acad Orthop Surg. 2012; 20(11): 715 - 724. https://doi.org/10.5435/ IAAOS-20-11-715.

8. Donati D, Frisoni T, Dozza B, DeGroot H, Albisinni U, Giannini S. Advance in the treatment of aneurysmal bone cyst of the sacrum. Skeletal Radiol. 2011; 40(11): 1461 - 1466. https://doi.org/10.1007/s00256-011$1202-7$.

9. Zileli M, Isik HS, Ogut FE, Is M, Cagli S, Calli C. Aneurysmal bone cysts of the spine. Eur Spine J. 2013; 22(3): 593 - 601. https://doi.org/10.1007/ s00586-012-2510-x.

10. Burch S, Hu S, Berven S. Aneurysmal bone cysts of the spine. Neurosurg Clin N Am. 2008; 19(1): 41 - 47. https://doi.org/10.1016/j. nec.2007.09.005.

11. Fay L-Y, Wu J-C, Huang W-C, Shih Y-H, Cheng $\mathrm{H}$. One-stage posterior resection is feasible for a holovertebral aneurysmal bone cyst of the axis: A case report and literature review. Surg Neurol. 2009; 72 Suppl 2: S80 - S85. https://doi. org/10.1016/j.wneu.2009.09.007.

12. Sartawi M, Quateen A, Nataraj A, Medairos R. Spinal intradural aneurysmal bone cyst: A case report. World Neurosurg. 2015; 84(2): 593.e1 5. https://doi.org/10.1016/j.wneu.2015.02.012.

13. Pogoda P, Linhart W, Priemel M, Rueger JM, Amling M. Aneurysmal bone cysts of the sacrum. Clinical report and review of the literature. Arch Orthop Trauma Surg. 2003: 123(5): 247 - 251. https://doi.org/10.1007/ s00402-003-0496-X.
14. Jaiswal A, Vijay V, Kori P, Shukla R. Aneurysmal bone cyst of thoracic spine: Case report and brief review of literature. BMJ Case Rep. 2013; 2013: bcr2013009265. https://doi.org/10.1136/ bcr-2013-009265.

15. Codd PJ, Riesenburger RI, Klimo Jr P, Slotkin JR, Smith ER. Vertebra plana due to an aneurysmal bone cyst of the lumbar spine. Case report and review of the literature. J Neurosurg. 2006; 105(6 Suppl): 490 - 495. https://doi. org/10.3171/ped.2006.105.6.490.

16. Mulhall KJ, Sheehan E, McCabe JP. Diagnosis and management of a sacral aneurysmal bone cyst causing sciatica in an adolescent. Eur J Orthop Surg Traumatol. 2003; 13(2): 121 - 123. https://doi.org/10.1007/s00590-003-0069-2.

17. Oliveira AM, Chou MM. USP6-induced neoplasms: The biologic spectrum of aneurysmal bone cyst and nodular fasciitis. Hum Pathol. 2014; 45(1): 1 - 11. https://doi. org/10.1016/j.humpath.2013.03.005.

18. Panoutsakopoulos G, Pandis N, Kyriazoglou I, Gustafson P, Mertens F, Mandahl N. Recurrent $\mathrm{t}(16 ; 17)(\mathrm{q} 22 ; \mathrm{p} 13)$ in aneurysmal bone cysts. Genes Chromosomes Cancer. 1999; 26(3): 265 - 266. https://doi.org/10.1002/(sici)10982264(199911)26:3<265::aid-gcc12>3.0.co;2-\#.

19. Oliveira AM, Hsi B-L, Weremowicz S, Rosenberg AE, Cin PD, Joseph N, et al. USP6 (Tre2) fusion oncogenes in aneurysmal bone cyst. Cancer Res. 2004; 64(6): 1920 - 1923. https://doi.org/10.1158/0008-5472.can-032827.

20. Aydin M, Togral G, Kekeç F, Arikan M, Güngör S. Painful, pediatric sacral aneurysmal bone cyst treated by curettage and fresh frozen allograft. Eklem Hastalik Cerrahisi. 2016; 27(2): 103 - 107. https://doi.org/10.5606/ehc.2016.22.

21. Brastianos P, Gokaslan Z, McCarthy EF. Aneurysmal bone cysts of the sacrum: A report of ten cases and review of the literature. Iowa Orthop J. 2009; 29: $74-78$.

22. Jevtich V. Aneurysmal bone cyst of the sacrum. Rofo. 1988; 148(2): 213 - 214. https://doi. org/10.1055/s-2008-1048181.

23. Simm PJ, O'Sullivan M, Zacharin MR. Successful treatment of a sacral aneurysmal bone cyst with zoledronic acid. J Pediatr Orthop. 2013; 33(5): e61 - 4. https://doi.org/10.1097/ BPO.0b013e318285c3a7.

24. Skubitz KM, Peltola JC, Santos ER, Cheng EY. Response of aneurysmal bone cyst to denosumab. Spine (Phila Pa 1976). 2015; 40(22): E1201 - E1204. https://doi.org/10.1097/ BRS.0000000000001027.

25. Vester H, Wegener B, Weiler C, Baur-Melnyk A, Jansson V, Dürr HR. First report of a solid variant of aneurysmal bone cyst in the os sacrum. Skeletal Radiol. 2010; 39(1): 73 - 77. https://doi.org/10.1007/s00256-009-0751-5.

26. Ghermandi R, Terzi S, Gasbarrini A, Boriani S. Denosumab: Non-surgical treatment option for selective arterial embolization resistant aneurysmal bone cyst of the spine and sacrum. Case report. Eur Rev Med Pharmacol Sci. 2016; 20(17): $3692-3695$.

27. Nas OF, Kaçar E, Buyukkaya R, Şanal B, Erdogan C, Hakyemez B. Treatment of sacral aneurysmal 
bone cyst with percutaneous sacroplasty. Spine J. 2016; 16(1): e1 - e2. https://doi.org/10.1016/j. spinee.2015.08.005.

28. Doss VT, Weaver J, Didier S, Arthur AS. Serial endovascular embolization as stand-alone treatment of a sacral aneurysmal bone cyst. $J$ Neurosurg Spine. 2014; 20(2): 234 - 238. https:// doi.org/10.3171/2013.11.SPINE13412.

29. Yildirim E, Ersözlü S, Kirbaş I, Özgür AF, Akkaya T, Karadeli E. Treatment of pelvic aneurysmal bone cysts in two children: Selective arterial embolization as an adjunct to curettage and bone grafting. Diagn Interv Radiol. 2007; 13(1): 49 - 52 .

30. Rajadhyaksha C, Connolly LP, Connolly SA, Treves ST. Aneurysmal bone cyst of the sacrum: Value of three-phase imaging. Clin Nucl Med. 2003; 28(11): 933 - 935. https://doi. org/10.1097/01.rlu.0000093092.31401.5c.

31. Derinkuyu BE, Boyunaga OL, Tekin-Orgun L, Ozdemir-Gokce A, Firat H, Demir E. Sacral aneurysmal bone cyst in a child presenting with radiculopathy. Spine J. 2016; 16(6): e391 - e392. https://doi.org/10.1016/j.spinee.2015.12.022.

32. Choudhury MZB, Tsirikos AI, Grainger MF. Spinal tumours: Diagnosis, clinical presentation and principles of treatment. Orthop Trauma. 2017;31(6): 411 - 421. https://doi.org/10.1016/j. mporth.2017.09.013.

33. Boriani S, Lo S-FL, Puvanesarajah V, Fisher CG, Varga PP, Rhines LD, et al. Aneurysmal bone cysts of the spine: Treatment options and considerations. J Neurooncol. 2014; 120(1): 171 - 178. https://doi.org/10.1007/s11060-014$\underline{1540-0}$.

34. Zhu S, Hitchcock KE, Mendenhall WM. Radiation therapy for aneurysmal bone cysts. Am J Clin Oncol. 2017; 40(6): 621 - 624. https:// doi.org/10.1097/COC. 0000000000000208 .

35. Barbanti-Brodano G, Girolami M, Ghermandi R, Terzi S, Gasbarrini A, Bandiera S, Boriani S. Aneurysmal bone cyst of the spine treated by concentrated bone marrow: Clinical cases and review of the literature. Eur Spine J. 2017:
26(Suppl 1): 158 - 166. https://doi.org/10.1007/ s00586-017-4978-X

36. Terzi S, Gasbarrini A, Fuiano M, Brodano GB, Ghermandi R, Bandiera S, Boriani S. Efficacy and safety of selective arterial embolization in the treatment of aneurysmal bone cyst of the mobile spine: A retrospective observational study. Spine (Phila Pa 1976). 2017; 42(15): 1130 - 1138 . https://doi.org/10.1097/ BRS.0000000000002017.

37. Pelle DW, Ringler JW, Peacock JD, Kampfschulte $\mathrm{K}$, Scholten $2^{\text {nd }} \mathrm{DJ}$, Davis MM, et al. Targeting receptor-activator of nuclear kappaB ligand in aneurysmal bone cysts: Verification of target and therapeutic response. Transl Res. 2014; 164(2): 139 - 48. https://doi.org/10.1016/j. trsl.2014.03.005.

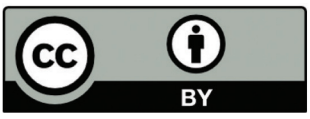

This work is licensed under a Creative Commons Attribution 